\title{
"Assessment of Coastal Vulnerability Index on potential agricultural land - CVI, Banyuwangi Regency“
}

\author{
Sukron Romadhona ${ }^{1}$, Laily Mutmainnah ${ }^{2}$, Cahyoadi Wibowo ${ }^{3}$, Tri Candra Setiawati ${ }^{4}$ \\ ${ }^{1234}$ Soil Science, University of Jember
}

\begin{abstract}
Indonesia is an archipelago country that has the longest coastline after Canada (UNCLOS). Banyuwangi District is a coastal area in Northern Java, which has a very dynamic development because of its location of the capital city that located along the coastal area. The purpose of this study is to assess the degree of coastal vulnerability in Banyuwangi District with the higher level of development. The CVI method (Coastal Vulnarability Index) of evisien sting is used to assess vulnerability. The coastal vulnerability is very low over 8 $\mathrm{km}$, with a $15.4 \%$ of coastal length of Banyuwangi District. Low vulnerability occurs in areas that are located in areas close to settlements area, with beaches already experiencing human intervention. The low category is about $12 \mathrm{~km}$ long, reaching 23.3\% of the existing coastal length in Banyuwangi District. The middle category is about $16 \mathrm{~km}$, equivalent to $30.8 \%$ of shoreline. While the high category is about $10 \mathrm{~km}$, equivalent to $19.2 \%$ of coastal length. The highest category has a length of $6 \mathrm{~km}$, equivalent to $11.5 \%$ of the coastal area of Banyuwangi district.

Keywords : Banyuwangi, CVI, Coastal Area
\end{abstract}

\section{INTRODUCTION}

Indonesia is an archipelago country which has the second largest coastline in the world; the first is Canada (UNCLOS). According to what is stated in Regulations that Unitary State of the Republic of Indonesia as an archipelago country which has sovereignty over its territory [24]. The immense amount of coastline is a valuable aspect for a country. Even though it would be a serious issue in term of management of the coastline. Indonesia's territory is often known in the world with as the Indonesian Maritime Continent with a total of 17,504 islands. The marine area reaches an area of about 7.9 million $\mathrm{km}^{2}$ or $81 \%$ of the total area comprising the territorial waters of the oceans, marine archipelago, and the sea of the Exclusive Economic Zone of Indonesia (ZEEI). The coastline of Indonesia is the second longest in the world after Canada. In a land area of 1.9 million $\mathrm{km}^{2}, 27 \%$ or about 0.54 million $\mathrm{km}^{2}$ are common inland waters and swamp areas such as rivers, swamps, lakes and reservoirs [13]

Banyuwangi is a district directly adjacent to East Java Province, to the north by the Java Sea. The location of the district is about $630-76$ 'south latitude and 111 00' - 11130 'east longitude (Central Bureau of Statistics of Banyuwangi District, 2016). Banyuwangi District has 14 sub-districts and 5's are directly adjacent to Java Sea [4].Most of the coastal Banyuwangi District is dominated by white sand and rock types in several locations. Types of vegetation dominating along the coast are the type of mangrove, coastal pine, pandanus and grass [14]The dynamic and complex multi-functional coastal environment is constantly changing due to the natural driving factors and human factors [14] This change affects a number of socio-economic activities of humans often contrary to the environmental concept occurring in these areas. The general influence of humans tends to trigger damage in the coastal areas that cause other problems so that the coastal ecosystem is also affected [1]. The coastal zone in all regions is under grave threat by climate change and recent sea level rise. Areas with relatively low elevation (ground level) will experience temporal or permanent flooding (Rob), while other areas will experience increased coastal erosion and abrasion.

The change of coastal area of Banyuwangi District is very dynamic, the onward of coastline that occurs around the coast covering wide area. This condition is caused coastal morphology which is very ramps and high sediment supply especially around outfall [20]. Most of the changes are due to human intervention. Coastal area development and coastal reclamation existed in many locations on a small scale up to a large scale. Reclamation clearly has a huge impact on the surrounding area, and the potential for abrasion to an open coastal area. This obviously becomes a very important coastal dynamics for consideration. Predicted coastline and land loss rates are essential for future coastal zone management planning, and assess the biological impact of habitat change or damage. Currently, longterm coastal planning and decision-making has been done gradually, if so, for the coastline of the country[22]. Most coastal areas are highly vulnerable to potential damage, due to human activities and naturally. If one of the ecosystems is disturbed it will directly affect the damage to other systems. The high level of development in the coastal region of Banyuwangi regency cannot be regarded as merely but also must be taken into account the impact of its development [21]. As the times progressed, geographic information systems technology made it 
easier, formerly only in some large laboratories that have the ability to process GIS as at Oak Ridge National Laboratory (ORNL) (Gornitz). With the increasingly ease in assessing coastal vulnerability supported by the growing data access and surveying gateways today many people are already using GIS technology in assessing coastal vulnerability as conducted by [2],[19]

This study is analyzed areas with different characteristics (coastal width, distance from coastal vegetation, coastal slope, rock outcrop percentage, distance from the depth of 20 meters under the sea level, and presence of estuaries to understand the different dynamics associated with land use of this

\section{RESEARCH METHODOLOGY}

\subsection{Research Location}

Banyuwangi Regency is located between $6^{\circ}$ 30 '- $07^{\circ} 60^{\prime}$ south latitude and between $111^{\circ} 00^{\prime}$ $111^{\circ} 30^{\prime}$ east longitude. The total area of the regency of Banyuwangi which is $101.408 \mathrm{Ha}$ is a wide area of the Regency compared to other regencies or cities in Central Java Province. Most (46.39\%) area of Banyuwangi Regency is lowland located in the north of Banyuwangi regency, while in the south it is relatively higher. This southern region has an altitude of 100-500 meters above sea level $(30.42 \%$ of the total area of Banyuwangi Regency) and the rest is at an altitude of $0-25 \mathrm{~m}$ and 500-1000 m. Banyuwangi Regency area of 45,205 ha $(46.58 \%)$ has a slope of $0-2 \%$, while 33,233 ha other $(43.18 \%)$ has a slope of $2-15 \%$. Hill and mountain areas with slopes of $15-40 \%$ and $>40 \%$ respectively $14.38 \%$ and $4.86 \%$ of the total area of Banyuwangi Regency [15]

\subsection{Methods}

This study was conducted using the CVI (Coastal Vulnerability Index) method of analyzing characteristic. width of beach, distance from coastal vegetation, coastal slope, rock outcrop percentage, distance from sea to sea 20 meters, and presence of estuaries, Coastal Vulnerability Index (CVI) resulting from the combination of these components are calculated, and presented in vulnerability maps (Barros et al.). The results of the study will highlight the different behaviors and dynamics among the study areas indicating the percentage of areas affected by the CVI class for all categories of areas analyzed. Beaches with mangrove and estuarine land use clearly have higher CVI's as compared to industrial and residential areas.

vulnerable coastal areas based on qualitative and quantitative methods. This research uses GIS technology (Geography Information System) [18] and [9] which is the most commonly used medium in CVI modeling. According to [10], there are several types of parameters in assessing vulnerable coastlines characterized by low coastal reliefs, declines, extensive coastline retreats, and high tidal and wave energy. The assessment process classifies the geological and environmental data variables into new "risk" variables. Each risk variables ranges from 1 to 5 and indicates the relative risk in the region against erosion or inundation. Quantitative calculations are based on variables assessed based on current conditions existing in the field covering geomorphological landscape, coastline change, coastal slope, relative sea level, tidal wave height, average mean tensile heights [22]. Based on the present condition of Banyuwangi regency mostly are subject to reclamation which causes the impact of decreasing of the area which is abated, while the accretion value is increasing.

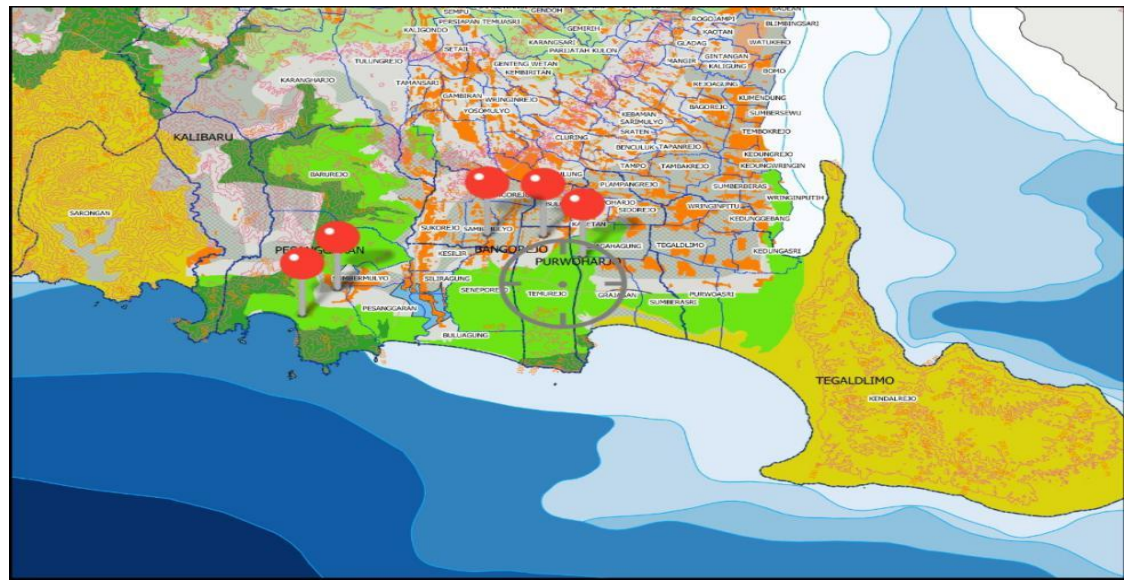

Figure 1. Research Location 


\subsection{Calculation of coastal vulnerability index}

In this study the calculation method follows a method that has long been used by, which is respectively also the same used by, and as the development is conducted by [18],[17]. CVI is designed to characterize the relative vulnerability of different coastal areas with respect to the possible impacts of climate change. This process may have various consequences, for example, can increase inundation levels, accelerate coastal erosion, and alter wave conditions. The original CVI procedure criteria, which are typically used for similar assessments along oceanic coasts that host a substantial tidal range, are revised in view of the specific litho-morphodynamic features of these low-lying low lands.

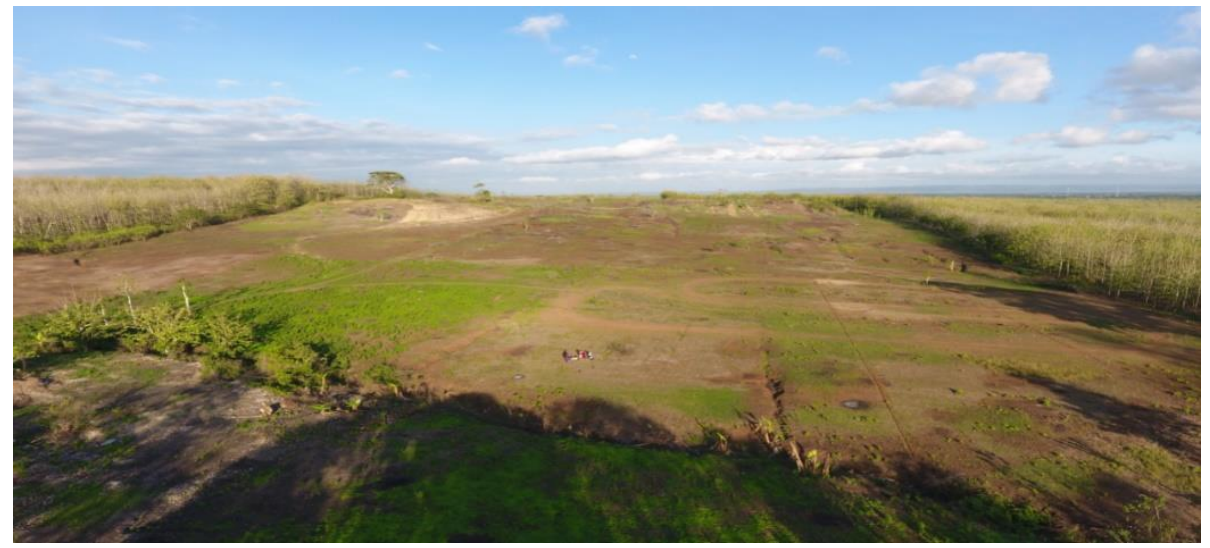

Figure 2. Research Location

The glossaries of the IPCC Third and Fourth Assessment Reports define vulnerability to climate change as the degree to which a system is susceptible to, and unable to cope with, adverse effects of climate change, including climate

Table 1. Data used in the study variability and extremes. According to the IPCC vulnerability is a function of the character, magnitude, and rate of climate change to which a system is exposed, its sensitivity, and its adaptive capacity

\begin{tabular}{llll}
\hline No & Parameter & Data & Year \\
\hline 1 & Geomorphology & Survey & 2017 \\
2 & Land Utilization & RTRW BAPPEDA & 2016 \\
3 & The depth of the sea & Bathymetry Gebco & 2009 \\
4 & Coastal slopes & Aster GDEM & 2011 \\
5 & Coastline changes & Landsat 7 and 8 & $2000-2017$ \\
6 & Tide range & Aviso Jason 2 & $2004-2017$ \\
\hline
\end{tabular}

Selected criteria are integrated into CVI calculations in two variations(Bagdanavičiute, Kelpšaite, and Soomere). Modification of assessment parameters is also done by [7],[8] to adjust the conditions in the field. Here is the equation used in the calculation of the coastal vulnerability index. 
Annotation:

$\mathrm{a}=$ Coastline changes

$\mathrm{b}=$ Average sea level (m)

$\mathrm{c}=$ The depth of the sea offshore $(\mathrm{m})$

$\mathrm{d}=$ Coastal slopes (degree)

$\mathrm{e}=$ Geomorphology

$\mathrm{f}=$ Land Utilization

The above parameters are widely used to adjust to the conditions of the sloping coastal areas parameters are also used by many experts such as and also have a high sedimentation consent, these [19]

Table 2. Coastal Vulnerability and Parameters

\begin{tabular}{|c|c|c|c|c|c|c|}
\hline No & Parameter & Very Low (1) & Low (4) & Average (3) & High (4) & Very High (5) \\
\hline A & Coastline changes & $>10$ & $2-10$ & $-2-1.99$ & $-10--2$ & $<-10$ \\
\hline $\mathrm{B}$ & Average sea level (m) & $<1.8$ & $1.81-2.5$ & $2.51-2.95$ & $2.96-3.16$ & $>3.16$ \\
\hline $\mathrm{C}$ & $\begin{array}{l}\text { The depth of the sea } \\
\text { offshore }(\mathrm{m})\end{array}$ & $<2.84$ & $1.80-2.84$ & $1.28-1.8$ & $0.76-1.28$ & $0.24-0.76$ \\
\hline $\mathrm{D}$ & Coastal slopes (degree) & $0-10$ & $11-20$ & $21-45$ & $46-60$ & $61-89$ \\
\hline E & Geomorphology & $\begin{array}{l}\text { Rocky } \\
\text { beaches, } \\
\text { cliffs, bays }\end{array}$ & $\begin{array}{l}\text { Medium } \\
\text { cliffs }\end{array}$ & $\begin{array}{c}\text { Low cliffs, } \\
\text { alluvial } \\
\text { plains }\end{array}$ & $\begin{array}{l}\text { Estuary, } \\
\text { lagoon }\end{array}$ & $\begin{array}{l}\text { Beach barrier, } \\
\text { Beach Sand, salt } \\
\text { marshes, flat } \\
\text { mud, delta, } \\
\text { mangroves, } \\
\text { coral reefs }\end{array}$ \\
\hline $\mathrm{F}$ & Land Utilization & Dry land & $\begin{array}{l}\text { Buildings, } \\
\text { plantations, } \\
\text { barren land } \\
\text { with } \\
\text { grasslands }\end{array}$ & $\begin{array}{l}\text { Plantation, } \\
\text { vacant lot }\end{array}$ & $\begin{array}{c}\text { Sandy } \\
\text { areas, } \\
\text { mangrove } \\
\text { s, } \\
\text { plantation } \\
\mathrm{s}\end{array}$ & $\begin{array}{l}\text { Beaches, } \\
\text { salt ponds, } \\
\text { aquaculture, } \\
\text { rivers, } \\
\text { swamps, } \\
\text { degraded } \\
\text { mangroves }\end{array}$ \\
\hline
\end{tabular}

\subsection{Geomorphology}

Geomorphology is defined as the study of the formation of land of origin and landscape, including descriptions, classifications, origin, development and history of the earth's surface so as to give a real picture of the phenomena in earth surface. Geomorphology seeks to identify order among the landscape and what processes produce patterns. It is a variable that experts use in assessing coastal vulnerability by

[9],[10]

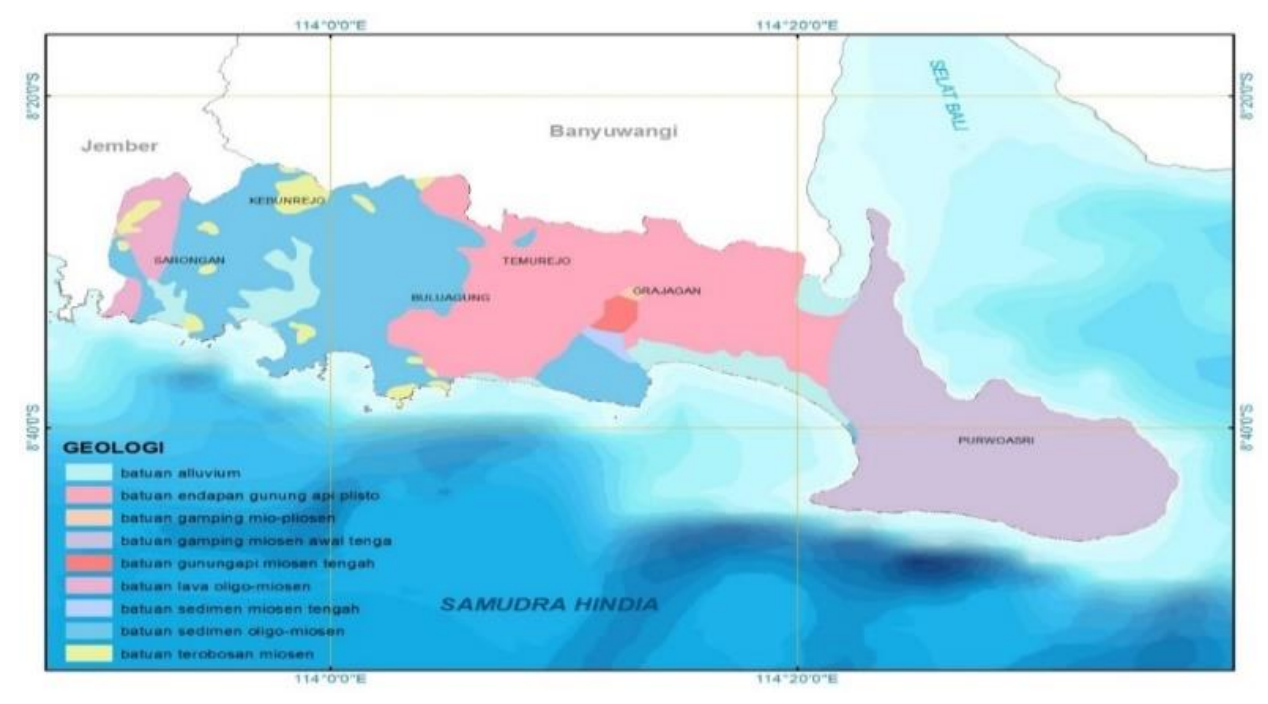

Figure 3. Geomorphology Classification

\subsection{Land Utilization}

Land utilization / land use maps are essential to understanding changes in land use classes / land in certain areas and how this helps in increasing or decreasing a region's vulnerability [8],[11], Land 
utilization data is data released by the district government [4]

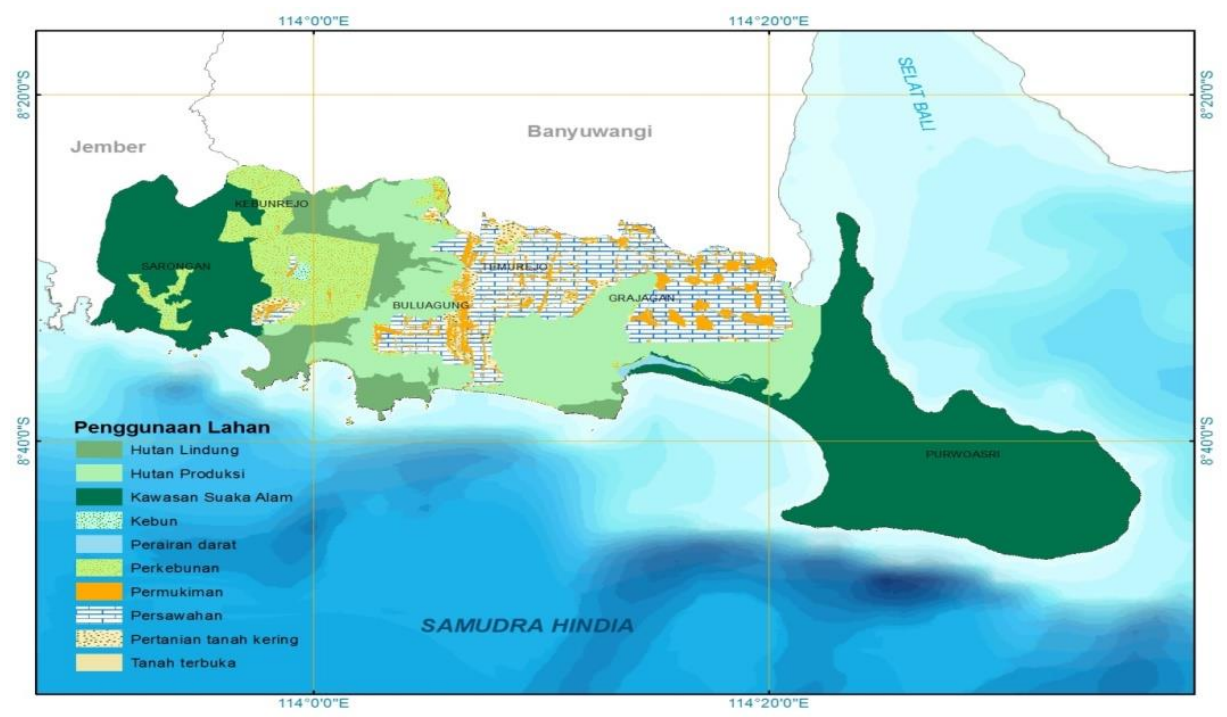

Figure 4. Land Utilization

\subsection{Coastal Slopes}

Coastal slope is often used as a parameter in determining coastal vulnerability. The lower the relief of the coastal slope, the higher the susceptibility of the coast to flooding and inundation, two major impacts predicted from increased frequency of extreme storm events and RSLR [12]. The slope is used to describe the measurements of steepness, slope, gradient, or straight line. The regional slope (percent) of the coastal zone is calculated from topographic and bathymetric elevation grids that span within a 10 $\mathrm{km}$ radius, towards the land and toward the sea, from the coastline [1]. The elevation data is obtained from GDEM Aster data (Aster Global Digital Elevation Mode) obtained from the USGS (United Stated Geology Survey), with a resolution of 1 'arc or with a resolution of $30 \times 30 \mathrm{~m}$ in its class can be seen in the Table. 1. For the current study, the slope map (Figure) has been generated using AsterGDEM data with a resolution of $30 \mathrm{~m}$. Coastal slope is calculated by using Arcgis software.

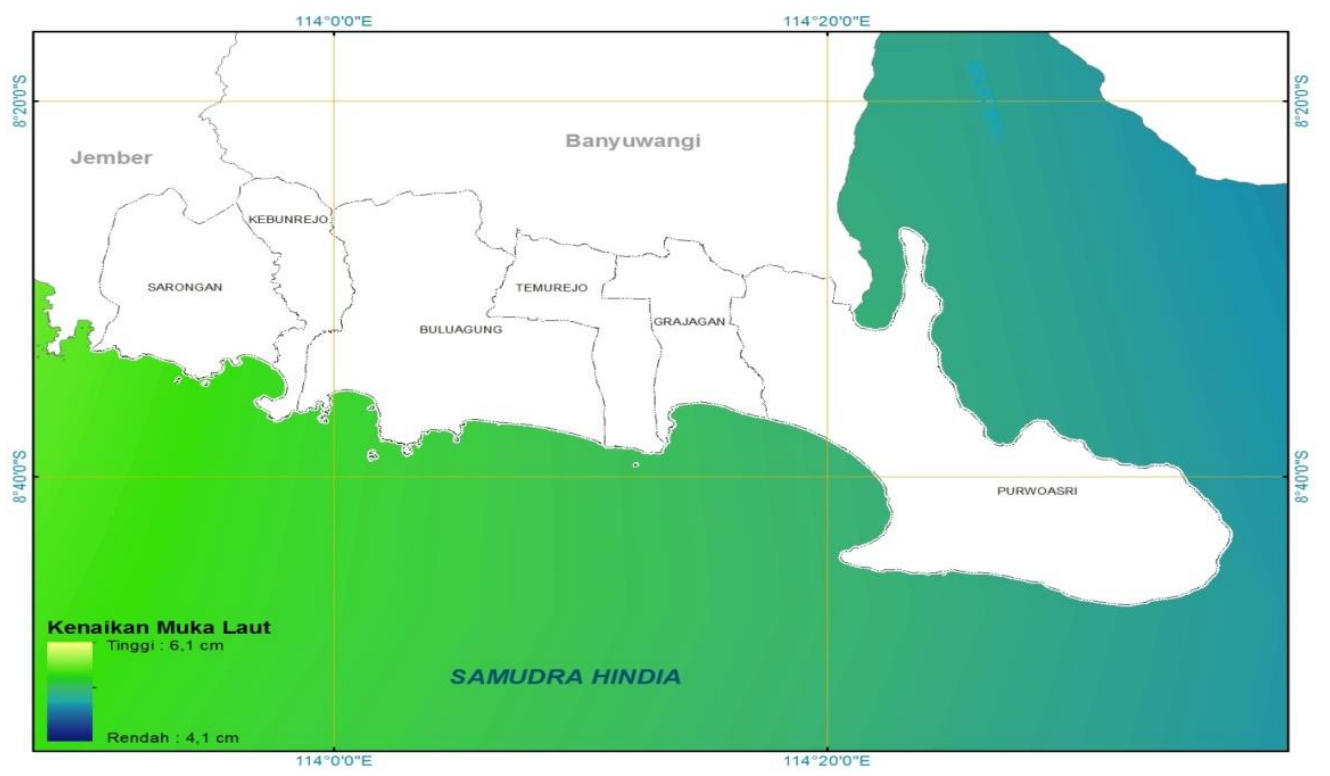

Figure 5. Coastal slopes

\subsection{The depth of The Sea}

Bathymetry shows the depth from the shore to the open ocean, it is the underwater equivalent. Line contours on land for this study GEBCO bathymetry data chart has been used to produce bathymetry maps. Based on [2], The depth contour has been developed using ArcGIS 10.1 after georeference with Universal Transverse Mercator (UTM) projection system with WGS-84 datum 
[16].

\subsection{Erosion Rate / Coastal Acceleration Rate}

The use of data from Landsat TM and ETM satellite imagery covering the study area in 1991, 2000, 2006, 2010 and 2017 is used in analyzing coastline changes, as multi-temporal recording templates are helpful in determining shoreline changes. Use of projected data to Universal Transverse Mercator (UTM) projection system with WGS-84 datum. Coastlines (images) from different years are digitized using Arc Map 10.1. Near

\section{DISCUSSION}

Banyuwangi regency is a coastal area mostly dominated by sandy beach areas, mangrove counters, ponds, and settlements. Some areas of Banyuwangi have very high sedimentation so that accretion occurs more dominant (Setiady and Usman). In addition to sedimentation, there is also a slump or reclamation in power plant development, and fishing boat dock. Settlements in coastal areas are fishermen's settlements adjacent to the sea. infrared bands most suited to groundwater [5]. demarcation have been used to extract the shoreline [19] while green bands are used to detect plants growing around the coast. The digital coastline for 1991, 2000, 2006, 2010 and 2017 in vector formats was used as input for the Digital Coastline Analysis System to calculate the rate of shoreline change. The input required for this tool is the coastline in vector format, the date of each vector layer, and the transect distance. The shoreline change rate is calculated for the entire study area, and the risk rating is set. Most experts use erosion as a basis, such as by [3].

Among the research sites are also mangrove land planted by the community, also salt ponds and fish ponds, there are also intensive ponds at some point. In addition to mangrove forests and ponds, there is also a sandy beach that is now a major tourist attractions by the government of Banyuwangi district.

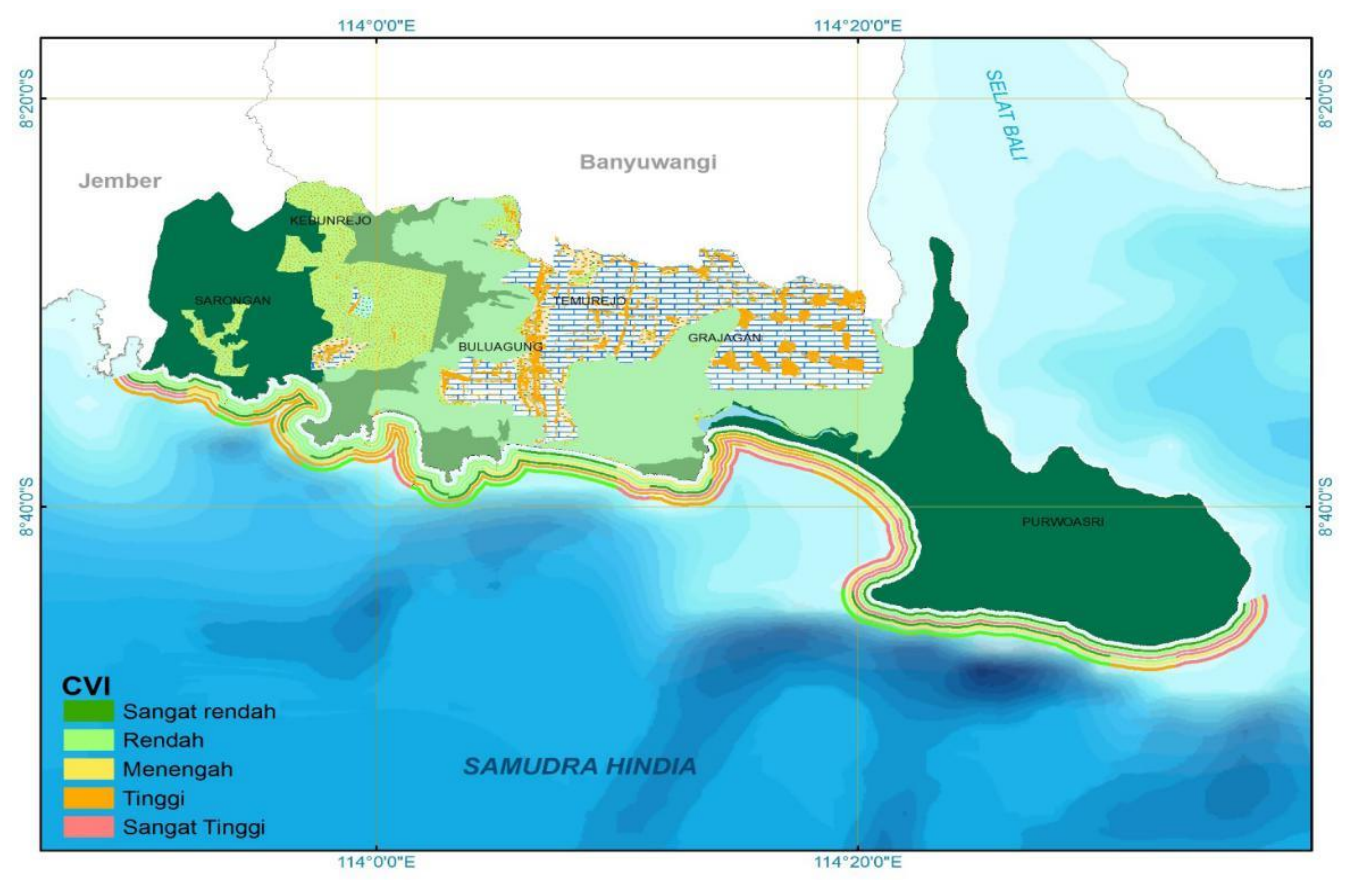

Figure 9. Coastal Vulnerability 


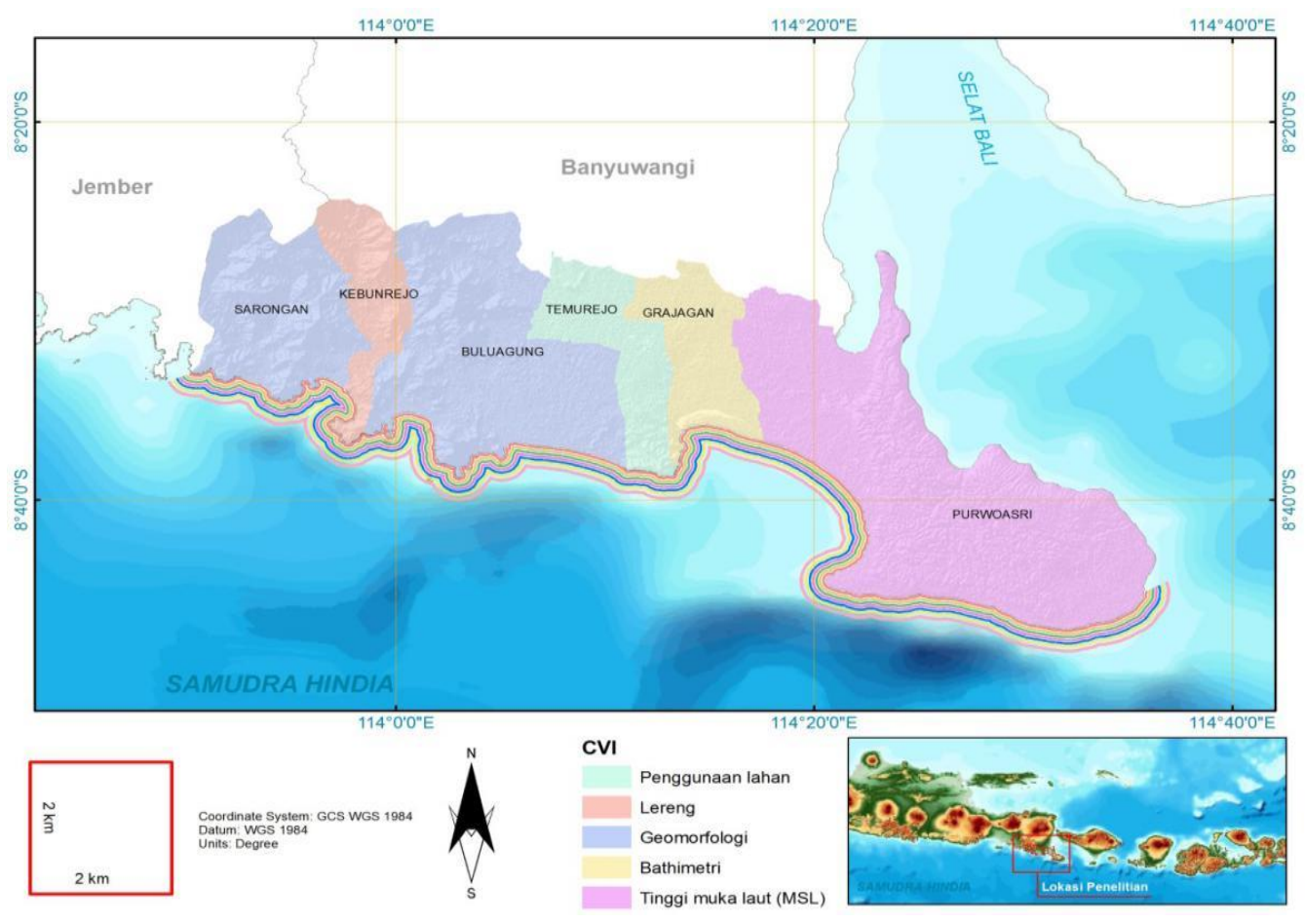

Table 3. Percentage of Coastal vulnerability rates in Banyuwangi district.

\begin{tabular}{lrrr}
\hline \multicolumn{1}{c}{ CVI } & TOTAL & KM & \% \\
\hline VERY LOW & 4 & 8 & 15.4 \\
LOW & 6 & 12 & 23.1 \\
AVERAGE & 8 & 16 & 30.8 \\
HIGH & 5 & 10 & 19.2 \\
VERY HIGH & 3 & 6 & 11.5 \\
JUMLAH & 26 & 52 & 100 \\
\hline
\end{tabular}

Most of the areas with high vulnerability are located in the mangrove forest area, which is in the area of mangrove rehabilitation. Most locations with very high vulnerabilities focus on protecting mangrove land use, coral reefs and seagrass beds. As part of the protection of wildlife habitats so as to have very high vulnerability. It also takes into account beaches, estuaries, and coastal slopes.

\section{CONCLUSIONS}

Areas with very low and very low vulnerabilities are mostly adjacent to settlements, with high sedimentation rates. Sandy areas usually fall into the middle category because they are vulnerable to beach damage and abrasion. Locations with high vulnerability adjacent to the mangrove forest site exist in the study area. The high vulnerability is beneficial in protecting mangrove forests to allow mangrove forests to be maintained.
The purpose of this preliminary assessment was to apply a CVI to the Westfjords, Iceland: a region particularly 'coastal' due to vast majority of settlement and infrastructure being located in the narrow space between steep fjordicwalls and the coastline. Palmer et al.'s (2011) CVI method was used as it included the use of physical parameters that are well-documented as offering indication of coastal vulnerability. Furthermore, these parameters could be measured using the limited available data. Upon applying this CVI method to the northernWestfjords, the majority of coastal sections scored similarly: in a possible range of $6-28,66 \%$ of coastal sections scored between 15-18

\section{ACKNOWLEDGEMENTS}

Acknowledgments to Prof. Aris Marfai, as mentors who provide input and a very big idea in this study. Acknowledgments to friends who have given support and prayers. 


\section{REFERENCE}

1. Addo, Kwasi Appeaning Journal of Coastal Research 165.65: 1892-1897. Web. (2013)

2. Ahammed, Kk. Basheer, Mahendra RS., and Pandey AC Geoinformatics \& Geostatistics June 2-8. Web. (2016)

3. Artese, G et al. XLI.July: 23-28. Web. (2016)

4. Badan Pusat Statistik Kabupaten Banyuwangi. "Banyuwangi Dalam Angka 2016." N.p.1-278. Print. (2016).

5. Bagdanavičiute, Ingrida, Loreta Kelpšaite, and Tarmo Soomere. Ocean and Coastal Management 104: 124-135. Web. (2015)

6. Barros, José Leandro et al. Water (Switzerland) 7.9: 4971-4998. Web. (2015)

7. Borges, $\mathrm{P}$ et al. The International Coastal Symposium 70: 385-388. Web. (2014)

8. Davies, W.T.R:109. Print. . (2012)

9. Gornitz, Vivien. 89.4: 379-398. Web. (1991)

10. Gornitz, Vivien $\mathrm{M}$ et al: Coastal and Estuarine Research Federation 12: 327-338. Print. (1994)

11. Hinkel, J. and Klein, R J T. Global Environmental Change, 19, 384- 395. (2009)

12. Lasabuda, Ridwan. Jurnal ilmiah Platax I :92101. Print. (2013)

13. Lilik, Kurniawan et al. "Indeks Kerawanan Bencana Indonesia: 1-226. Print. . (2011)

14. Loinenak, Frida Aprilia, Agus Hartoko, and Max Rudolf MuskananfolaInternational Journal of Technology 6.5: 819-827. Web. (2015)

15. Mani Murali, R. et al.." Natural Hazards and Earth System Sciences 13.12: 3291-3311. Web. (2013)

16. Nicholls R.J. and Klein R.J.T., Managing European Coasts: Past, Present and Future. Germany, Spinger. (2015)

17. Pendleton, E A et al. OFR 2010-1.July 2010: n. pag. Web. (2010)

18. Pendleton, Elizabeth a et al. U.S. Geological Survey Open-File Report 2004-1090: 1-23. Print. (2004)

19. Sankari, T. Siva et al. Aquatic Procedia 4.Icwrcoe :412-418. Web. (2015)

20. Setiady, D, and E Usman. 6.236: 146-153. Print. (2008)

21. Setyawan, Ahmad Dwi. Biodiversitas, Journal of Biological Diversity 7.2: 159-163. Web. (2006)

22. Thieler, E. Robert, and Erika S. Hammar-Klose. Open-File Report 00-179: 99-593. Print. (1999)

23. Thieler, Er, and Es Hammar-Klose US Geological Survey 78.37: 1997. Web. (2000)

24. Undang - Undang No 43 tahun 2008. "UNDANG-UNDANG REPUBLIK INDONESIA NOMOR 43 TAHUN 